\title{
THE REDISCOVERY OF A SOCIETY ISLANDS TAMAU, OR HEADDRESS OF HUMAN HAIR, IN THE “COOK-VOYAGE” FORSTER COLLECTION AT THE PITT RIVERS MUSEUM -AND A POSSIBLE PROVENANCE
}

\author{
JEREMY COOTE and JEREMY UDEN \\ Pitt Rivers Museum, University of Oxford
}

A famous moment in the history of the study of Polynesian art was recounted by B.A.L. Cranstone and H.L. Gowers in a contribution to the British Museum Quarterly in 1968. In it they reported on the dismantling of a Tahitian mourner's dress believed to have been collected on James Cook's second famous voyage to the Pacific on HMS Resolution in 1772-75. This had been on display in the Polynesian section of the "ethnographical gallery" at the British Museum until late 1966 when the exhibition was subjected to a partial rearrangement. In particular, they described the step-by-step disassembling of the headpiece and reported that:

\footnotetext{
Removal of this barkcloth hood revealed that the solid support inside it was in fact a complete wooden human figure of considerable sculptural merit, carved in traditional Tahitian style, the existence of which had not hitherto been known. Its discovery naturally caused some excitement since these figures are not common and the addition of one to the corpus of Cook material is not an everyday event. (Cranstone and Gowers 1968: 141)
}

The figure was assigned the British Museum registration number TAH 78A (the mourner's dress was already numbered TAH 78) and has gone on to have an illustrious career, featuring in the famous "Artificial Curiosities" exhibition in Honolulu in 1978 (see Kaeppler 1978a: 136 and 137, Fig. 236) and, more recently, in the major "Cook" exhibition that opened in Bonn in 2009 and toured to Vienna and Berne in 2010-11 (see Jessop 2009). ${ }^{1}$

More than 40 years later, in July 2010, Uden set about dismantling the Tahitian mourner's dress in the collections of the University of Oxford's Pitt Rivers Museum, in order to conserve and research the component parts before preparing it for redisplay. This dress is known to have been collected on Cook's second voyage, having formed part of a collection of more than 220 "curiosities" that Johann Reinhold Forster and his son Johann George gave the University in 1776 after serving as naturalists on the Resolution 
(Coote, Gathercole and Meister 2000). The collection was housed at the University's Ashmolean Museum until 1886, when it was transferred to the newly founded Pitt Rivers Museum.

Uden's sense of anticipation at the prospect of working with such important material was heightened by the possibility that a discovery similar to that reported by Cranstone and Gowers might be made. Given that the dress had been dismantled as recently as 1970, in preparation for its display in a special exhibition devoted to the Forsters' collection, "From the Islands of the South Seas, 1773-4" (Gathercole no date [1970]; see also Coote 2005), it seemed unlikely that any major discovery would be made. Moreover, although that dismantling and reassembly had not been documented according to 21 st-century conservation standards, it had been recorded photographically, and there was nothing in the surviving images to suggest that any stray figures or other objects might have found their way into the dress and were waiting to be discovered there (see, for example, Fig. 1 here). ${ }^{2}$ Nevertheless, there was a palpable sense of excitement in the museum's conservation studio as the process of dismantling the dress was begun. As it turned out, Uden was to make not a "discovery" of a previously unknown piece, but a "rediscovery" of a previously missing object.

\section{A HYPOTHESIS}

In fact, some ten years earlier the possibility that a Society Islands tamauthat is, a headdress made of plaited skeins of human hair - might be concealed within the dress had been raised by Coote. When Anne D'Alleva examined the dress in June 1994, as part of her doctoral research into the art of 18th-century Tahiti and the Society Islands more generally, she noted that the tying cords around the barkcloth turban in the dress's headpiece were "wrapped with finely braided human hair, tamau" (D'Alleva 1997: 562). After a second examination in January 2001, she stated that the dress "incorporates whole skeins of tamau in its headpiece" (D'Alleva 2001: 85). On both occasions, D'Alleva's examination of the dress had been hampered by its being on display in the Museum in a cramped case-as a result her investigation was limited to what was immediately visible or could be seen with some gentle lifting and separating of the overlayered parts. She had been able to make out the presence of braided human hair, but had not been able to investigate further.

As D'Alleva's wording indicates, what she had glimpsed was not a tamau headdress as such, but merely skeins of hair wrapped around the headpiece's barkcloth turban; these skeins also being known - a little confusingly for present purposes - as tamau. However, her reference to tamau struck a chord with Coote for, since he had begun to take an interest in the Forster Collection 


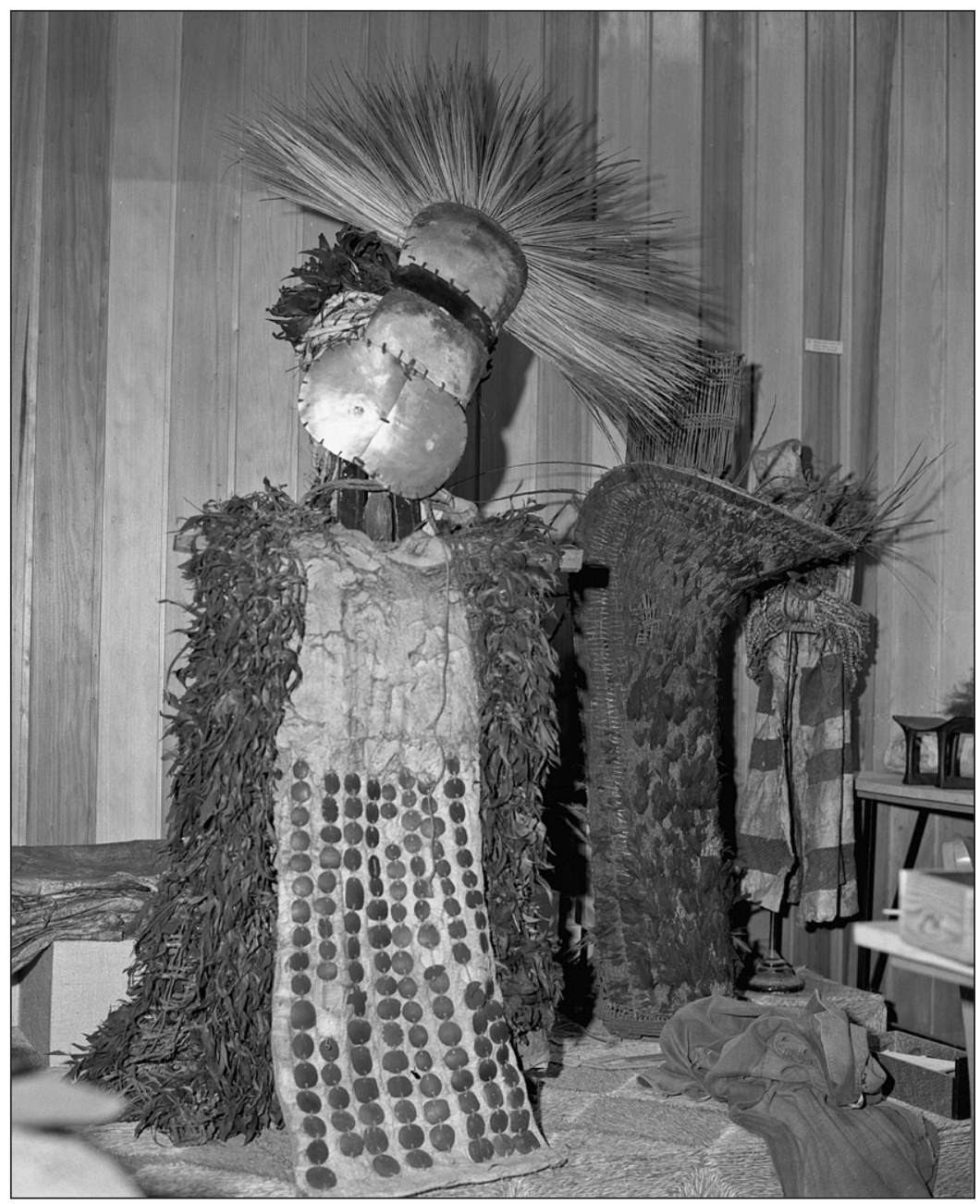

Figure 1. View of the partially assembled Tahitian mourner's dress during the preparations for the special exhibition "From the Islands of the South Seas, 1773-4" at the Pitt Rivers Museum in April 1970; from a photograph taken for the Museum by Peter Narracott (PRM000011658; PRM neg. R1.3). Courtesy and copyright, Pitt Rivers Museum, University of Oxford. 
in the mid-1990s, he had been aware that the Forsters had included a tamau headdress in the collection they gave to the University of Oxford in 1776 and that it had not been seen nor heard of since. As it happens, even the very fact that the Forsters' donation had included a tamau had not been known to Museum staff or the wider scholarly community until 1969 when Adrienne Kaeppler "rediscovered" the Forsters" manuscript "Catalogue of Curiosities sent to Oxford" (Kaeppler 1972). Indeed, it was only once Kaeppler had made her discovery that the full extent of the Forsters' collection became known. The tamau listed by the Forsters as number 40 under the heading "OTaheitee and the Society Isles", that is, "The Tamow, or Headdress of platted hair" (Coote et al. 2000: 188), is one of some 30 objects for which no later record exists. In particular, there is no record for a tamau at either the University's Ashmolean Museum (where the collection was originally housed) or the Pitt Rivers Museum (to which the collection was transferred in the mid-1880s); the only record for it is in the Forsters' manuscript catalogue. From 1969 onwards, therefore, the Forster-collection tamau was regarded as "missing".

As it happens, rediscovery of the Forsters' manuscript catalogue had been made in time for Peter Gathercole to list the tamau as "missing" in his Short Guide to the 1970 exhibition (Gathercole no date [1970]). Kaeppler also included it - again as "missing"-in the section devoted to "Tahiti... Ornaments of Hair" in her comprehensive listing of Cook-voyage artefacts in the catalogue of the "Artificial Curiosities" exhibition (Kaeppler 1978a: 131). Since 1994, when he started to take an interest in the Forster collection, the tamau headdress had been one of the objects that Coote had been hoping might "turn up". Given that there was no record for it at either the Ashmolean or the Pitt Rivers, however, it seemed unlikely that it had survived. Nevertheless, along with every other item listed by the Forsters, in 2001 Coote (2001a) created an entry for it in the website dedicated to the collection, ${ }^{3}$ but without being able to say much about it, other than it was missing.

D'Alleva's references to skeins of hair in the headpiece of the mourner's dress, therefore, raised Coote's hopes that the missing headdress might somehow have been incorporated into it. Thus, in September 2001 he added the following speculative note to the entry for the missing item in the online database for the Forster Collection:

it has occurred to me that this item may have been incorporated into the mourning dress without a separate record for it having been made. In particular, it might have been incorporated into Forster 2 (PRM 1886.1.1637.6), 'the Turband called Ta-oopo consisted of many sorts of their cloth pasted together, and ornamented with cords of the same'. That this possibility is worth investigating is encouraged by Anne D'Alleva's discovery during 
a re-examination of 'the Oxford mourning dress' in January 2001 that it 'incorporates whole skeins of tamau in its headpiece'. (Coote 2001a)

Coote concluded by noting that, "along with a number of other queries, the resolution of this question will have to await a new, detailed study, and thus dismantling, of the mourning dress as currently displayed in the Museum". Which is, of course, exactly what Uden embarked on in July 2010.

\section{DISCOVERY, DESCRIPTION, AND CONSERVATION}

On 5 July 2010, the mourner's dress at the Pitt Rivers Museum was removed from display to the Museum's conservation studio. Uden and his colleagues then set about dismantling the dress into its component parts (Uden 2011a, 2011b). As it was disassembled, it was clear that the headpiece comprised a pandanus cap, from which hung a barkcloth cape, and on which rested a hair-wrapped barkcloth turban supporting a feather headdress. As soon as the headpiece was separated from the rest of the dress, however, it became apparent that there was a large quantity of hair both around and under the turban's bindings. By this stage it could already be seen that there was also a mass of hair underneath. In order to reveal what was hidden it was necessary to unwind the bindings (Fig. 2). The knots securing the ends of the bindings were untied, and the bindings slowly unwound. It turned out that three sections of binding had been used: two shorter pieces measuring 6.25 and 10.1 metres, each of which consisted of a core of coconut fibre cord wrapped around with narrow lengths of barkcloth and then strands of plaited human hair; and a longer piece, measuring 12.1 metres, which had a core of plaited hair, also wrapped around with barkcloth and human hair. Once the bindings had been removed, it was apparent that the mass of hair was actually a tamau headdress that had been placed directly on to the pandanus-leaf cap that was the basis of the structure of the headpiece (Fig. 3).

Once it had been removed, it was possible to examine the tamau more closely. It was clear that the tamau had suffered a good deal of moth damage, with many of the strands having been broken. Moreover, the hair was dry and brittle. In order to allow it to return to something like its original appearance, the tamau was humidified with the water vapour heated to 40 degrees centigrade. This made the hair stronger and more lustrous, and of its own accord it returned to what we may assume was more or less its original form (Fig. 4). During this process much frass (insect excreta and related debris) fell out, together with powdery residues formed from the breakdown of the hair. In addition, a few fragments of plant material were caught in the hair. These may well be remains of the plants with which tamau were both filled and decorated when they were being prepared for use in a dance (see below). ${ }^{4}$ 


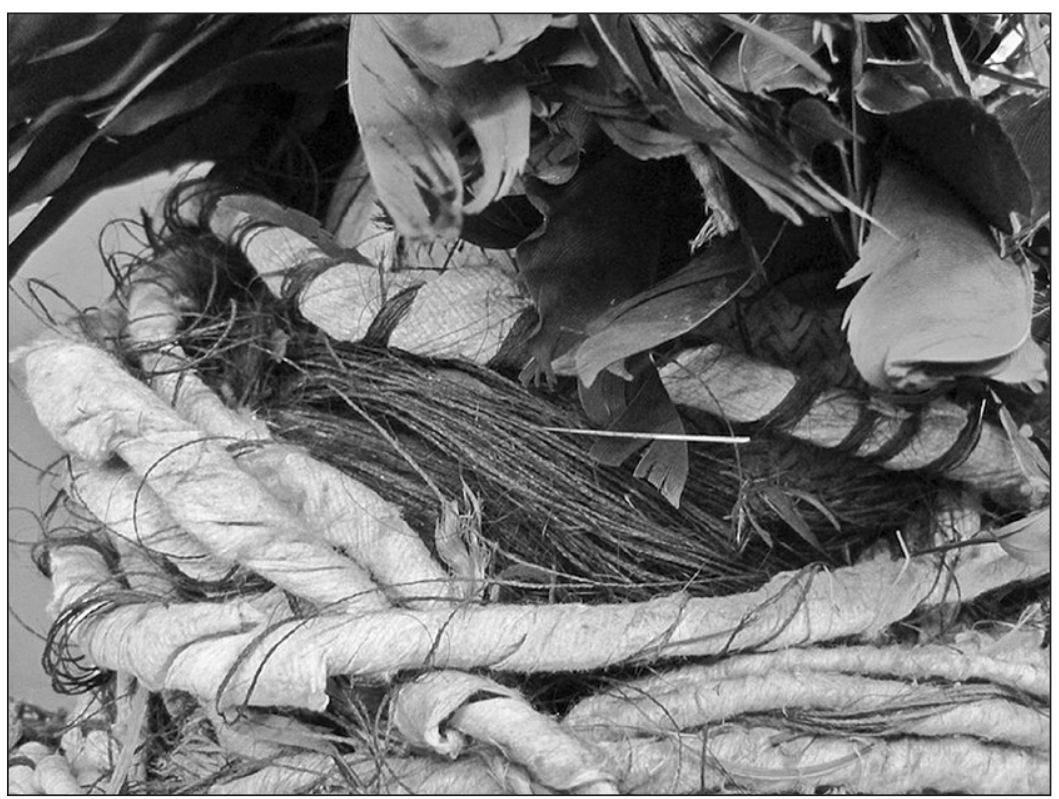

Figure 2. Close-up of the Tahitian mourner's dress in the process of being dismantled in July 2010; although the feather headdress and the barkcloth turban have not yet been removed, the tamau is already visible; from a photograph taken for the Museum by Jeremy Uden (PRM000130296). Courtesy and copyright, Pitt Rivers Museum, University of Oxford.

The location of a large handwritten label, which had been pasted on to the hat under both the bindings and the headdress, was puzzling. This is one of the labels prepared by Edward Evans, underkeeper at the Ashmolean from 1879, who was given the task of cataloguing the Ashmolean's ethnographic collections in preparation for their transfer to the Pitt Rivers in the mid1880s. Drawing on the inventories, notes and labels of his predecessor George Augustus Rowell, as well as his own research, Evans compiled an extraordinarily detailed set of catalogue entries preserved in two manuscript volumes now held at the Pitt Rivers Museum, ${ }^{5}$ and also prepared detailed labels, which he pasted on to the objects themselves. Evans could not have stuck this label on to the hat without removing the tamau, which in turn would have required the untying and unwinding of the bindings and the disentangling of the feather headdress. 


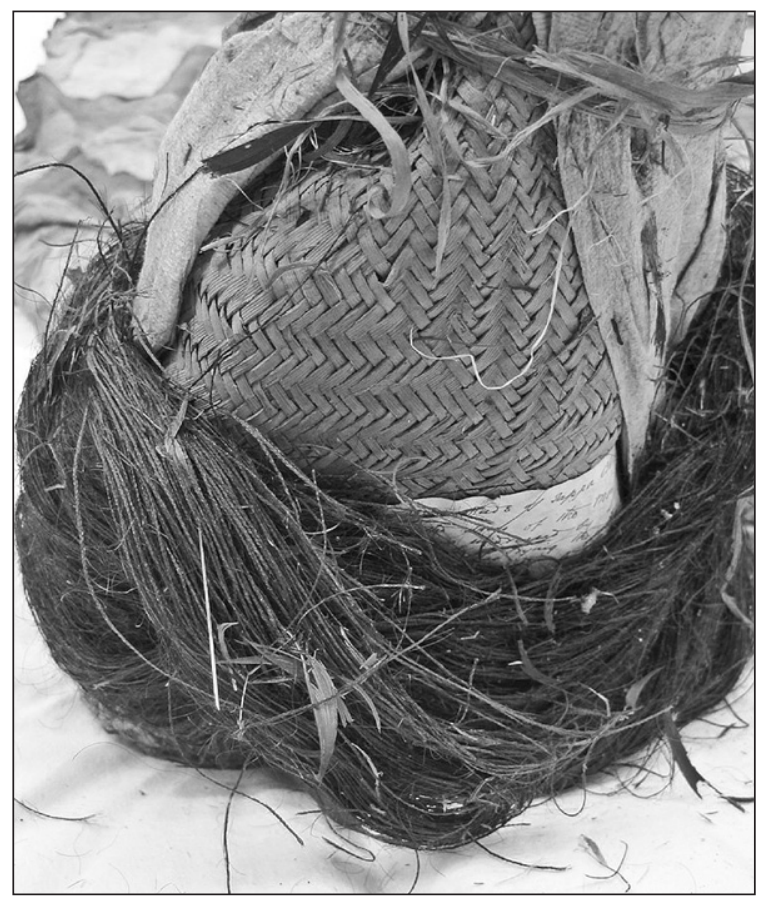

Figure 3. The headpiece of the Tahitian mourner's dress in the process of being dismantled in July 2010. The feather headdress and the barkcloth turban have been removed, but the barkcloth cape and the tamau remain attached to the pandanus cap; from a photograph taken for the Museum by Jeremy Uden (PRM000130294). Courtesy and copyright, Pitt Rivers Museum, University of Oxford.

When Uden "discovered" the tamau, there was no label on it, but it was immediately clear that it was a separate object and that it was the missing item given by the Forsters to the University in $1776 .{ }^{6}$ It was duly accessioned into the Museum's collections, being given the accession number 1886.1.1685 ("1886.1." being the prefix retrospectively assigned to the collection transferred from the Ashmolean in the mid-1880s, and " 1685 " being the next unused number in the sequence).

It is not known for sure when the tamau was incorporated into the mourner's dress, but it was presumably done soon after the arrival of the Forster Collection in Oxford in early 1776. This would help to explain why 


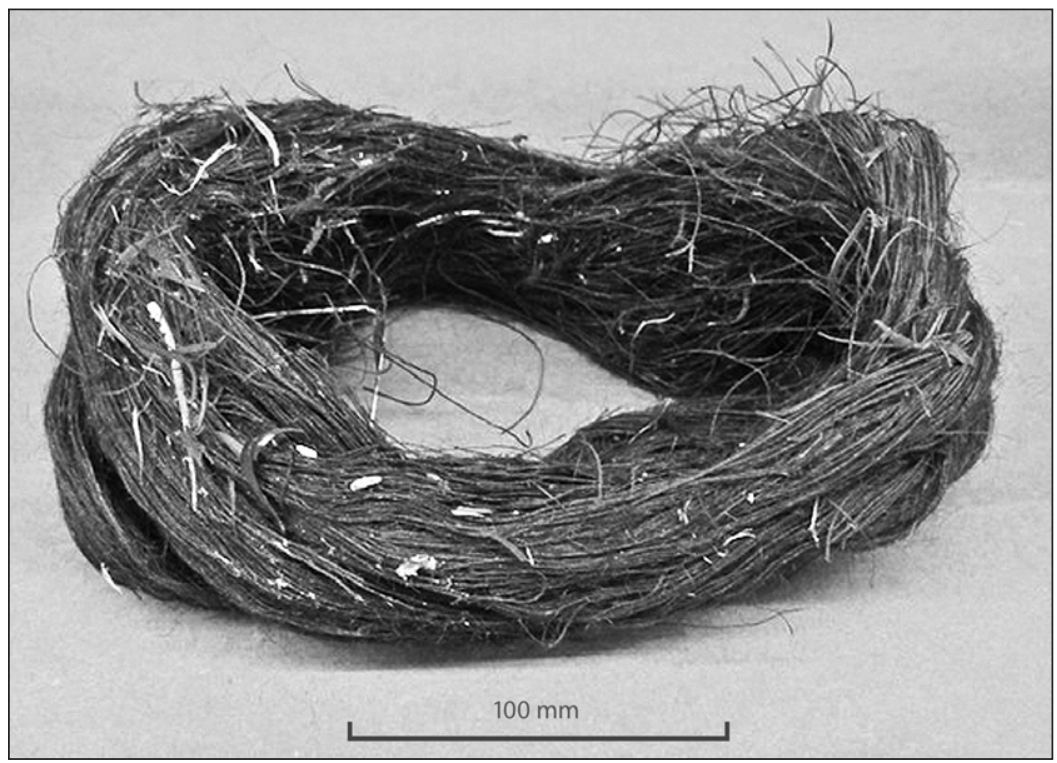

Figure 4. The tamau in July 2010; from a photograph taken for the Museum by Jeremy Uden (PRM000130297). Courtesy and copyright, Pitt Rivers Museum, University of Oxford.

there is no record of its existence in any of the documentation at either the Ashmolean or the Pitt Rivers museums. Given that the tamau was listed separately by the Forsters in their manuscript catalogue, we can be confident that it was not incorporated before the collection reached Oxford; and given that the tamau was not listed as a separate item when the Forster Collection was transferred to the Pitt Rivers in the mid-1880s, it seems virtually certain that it was incorporated before then. Moreover, we know from the account of a visit to Oxford by Danish scientist Thomas Bugge that the dress was mounted for display at the Ashmolean by 11 October 1777: "There are costumes and other curiosities from the South as well as from Otaheite. A man dressed for war, and another figure in mourning. They correspond exactly to the drawings found in Cook's voyages" (see Pedersen and de Clerq 2010: 124-5; also Ovenell 1986: 169). We can thus conclude that the tamau had almost certainly been incorporated by October 1777; that is, it appears that almost immediately after the dress had been donated to the University it was set up for display at the Ashmolean with the tamau incorporated into 
it. Presumably, the resemblance between the hair binding on the barkcloth "turban" and the hair of the tamau itself was enough to suggest to the staff of the Ashmolean at the time that the two went together. It also seems clear that when the headpiece was dismantled in the early 1880s (which it must have been for the label to have been stuck on to the pandanus cap), it was put back together more or less as it had been found, that is, again incorporating the originally separate but unrecognised tamau.

\section{TAMAU}

Anne D'Alleva notes that tamau "present a challenge to interpretation...for there is little direct exegesis of these artworks in Tahitian or early-voyage sources" (D'Alleva 2001: 82). As we see it, a necessary preliminary step is to note that the term was applied not only to the type of headdress discussed here, but also to the plaited hair from which such ornaments were made, and which also was used to make and decorate other objects. From the accounts of the early voyagers, we know that Society Islanders placed a high value on such plaited hair. Joseph Banks noted that "the rich have enormous quantities" of it (see Beaglehole 1962 [v. II]: 332), and it appears that such reserves were drawn on whenever a tamau was required; any headdress would thus be likely to be made up of the hair of a number of different - presumably relatedwomen (D'Alleva 2001: 85). Probably anything made from or incorporating such plaited hair was highly valued, and the headdresses certainly were. Banks noted that the tamau was the ornament "they value more than any thing they have" (see Beaglehole 1962 [v. I]: 324); while in the official account of the third voyage Cook noted how, along with taumi, or breastplates, tamau were the sort of very valuable objects which Tahitian thieves were severely punished for stealing (Cook and King 1785 [v. II]: 172; see D'Alleva 2001: 83).

Drawing on the accounts of Banks, Cook, the Forsters, and other voyagers, as well as later literature, and examination of examples surviving in museum collections, D'Alleva has provided the two most detailed accounts of what is known about the manufacture, use and significance of tamau in all its forms, as well as its place in a comparative Polynesian context. Thus we draw here on both her doctoral thesis (D'Alleva 1997: 255 ff.) and her later essay "Captivation, Representation, and the Limits of Cognition: Interpreting Metaphor and Metonymy in Tahitian Tamau" (D'Alleva 2001), though our account mostly leaves aside questions of meaning and significance, which D'Alleva and other specialists are better qualified than us to discuss.

Based on her examination of a number of examples, but not - for reasons already explained - the example reported on here, D'Alleva noted in 1997 that "the bundles of braided hair that survive... exhibit a remarkable uniformity of construction" (D’Alleva 1997: 257). Here is her later, generalised description: 
Each skein consists of a very fine three-ply braid, with each ply typically composed of anywhere from fifteen to thirty-five strands of hair. The hair itself is uniformly brown and straight, and perhaps it was sorted for colour and texture, for there are never grey or curling hairs in evidence. While the fineness and evenness of the braiding is remarkable, what is most impressive about tamau is their great length, seemingly many yards, and the fact that the braids are absolutely seamless. It is impossible to distinguish where hair has been added to create such long, smooth braids. (D'Alleva 2001: 85)

As D'Alleva also points out, "the tamau bundles extant today are too fragile to unwind and measure" (D'Alleva 1997: 258). However, estimates have been made concerning the dimensions of other surviving examples, and we offer below our own estimate for the example preserved at the Pitt Rivers Museum. The example collected on Cook's second voyage by Anders Sparrman, now in Stockholm, "made of black human hair made into a number of plaits consisting of three-ply string", is said to measure $500 \mathrm{~cm}$ (Söderström 1939: 33). Thomas Psota estimates that "in its original form" the plaited hair in the third-voyage example collected by John Webber, now in the Historisches Museum in Bern "was 80 to 100 metres in length and was wound into a thick bun with 200 to 250 turns" (Psota 2009). However, Joseph Banks claimed that "a common head dress contains at least 2 Leagues" and that he had "measured a peice [sic] made upon an end without a knot above an English mile and three quarters in Lengh [sic]" (see Beaglehole 1962 [v. II]: 332). Given that a league was equivalent to approximately three miles, Banks is claiming that tamau were commonly made of braided strands measuring longer than six miles or nine kilometres. ${ }^{7}$

The newly discovered headdress differs from D'Alleva's generalised description in that each ply consists of between six and ten, rather than between 15 and 35 strands of hair (see Fig. 5). We cannot say why the newly discovered example differs in this way from those examined by D'Alleva, though it may perhaps be a local variant. As for its dimensions, since its humidification and passive reshaping, it has a maximum length of $285 \mathrm{~mm}$ and a maximum width of $200 \mathrm{~mm}$. More precisely perhaps, it weighs 164 $\mathrm{gm}$, this providing a starting point for assessing the total length of the braided strands. Our various calculations lead us to estimate that the plaited hair in the Oxford tamau measures between two-thirds of a kilometre and one kilometre. ${ }^{8}$

The rediscovered tamau is one of only a few that can be traced to Cook's voyages or to the 18th century more generally. In the "Tahiti and Society Islands" section of her "Artificial Curiosities" catalogue, Kaeppler (1978a: 131-32) lists nine "ornaments of hair" that can be provenanced to Cook's voyages (some only circumstantially). As noted above, despite being "missing" at the time, the present example was included by Kaeppler in 


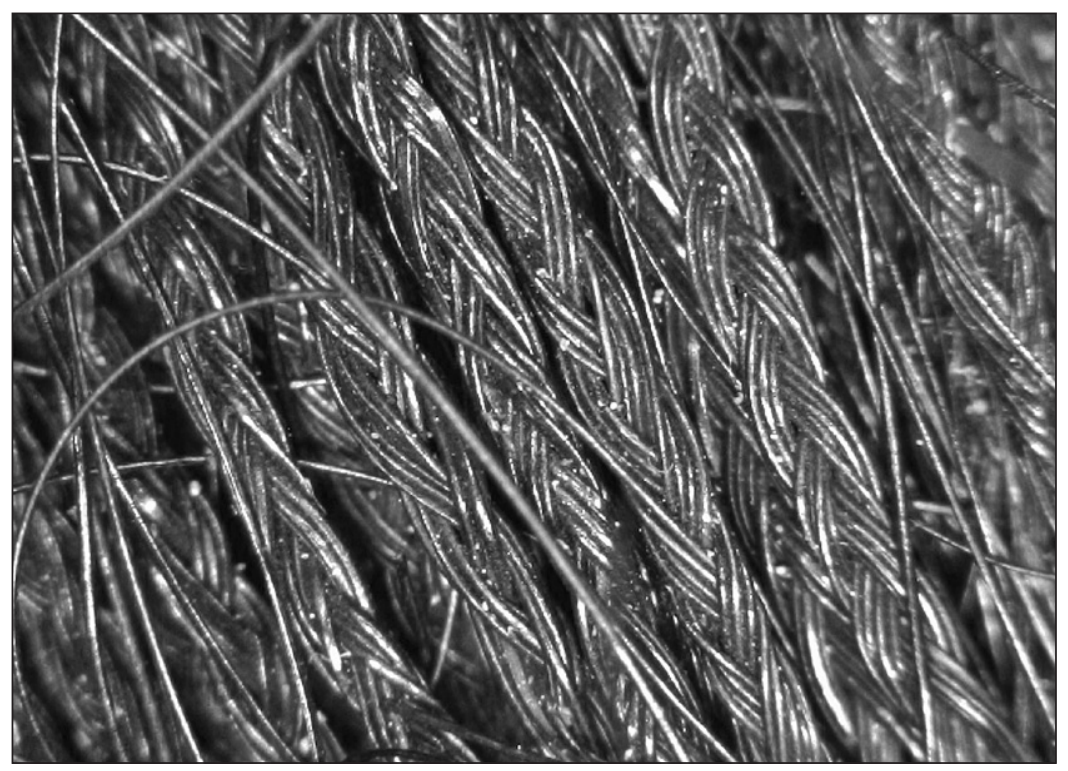

Figure 5. Microscopic detail of the plaited hair in the tamau in July 2010, from a photograph taken for the Museum by Jeremy Uden (PRM000130298). Courtesy and copyright, Pitt Rivers Museum, University of Oxford.

her list of nine examples. In her doctoral thesis, D'Alleva listed 11 "hair ornaments" as having "secure eighteenth-century provenance", of which she specifically identifies seven as tamau (D'Alleva 1997: 540-44); and she lists a further five (all identified as tamau) of "probably eighteenthcentury provenance" (pp. 636-37). Because its whereabouts were unknown at the time of her research, D'Alleva did not include the present example in either of her lists. ${ }^{9}$ There may be other examples awaiting discovery in museum collections, but it is clear the tamau collected in 1773-74 by the Forsters and now rediscovered at the Pitt Rivers Museum is one of very few attested early examples and thus part of a limited corpus. Indeed, given that D'Alleva stated in both 1997 and 2001 that "no headdress survives intact today" (D'Alleva 1997: 256, 2001: 84), it is worth stressing that the present example appears to be as close to intact as one could expect a 240 -year-old ornament of human hair to be. From what we have been able to gather from the literature about the other surviving examples, in both headdress and "loose" forms, it is also the best preserved. 


\section{A POSSIBLE PROVENANCE}

Our original intention in preparing this article was only to report the "rediscovery" and provide a description. However, we are encouraged by D'Alleva's discussion of the number of references in the voyaging and other early literature to tamau being presented by high-ranking women to particular European visitors to at least consider whether a likely source might be suggested for the example preserved at Oxford. As D'Alleva's discussion demonstrates, that the Forsters might have been given a tamau by a woman would not be surprising, given what is known about gift-giving during the early European voyages. Drawing on the log book of the voyage of the Dolphin, D'Alleva says that "during the first European voyage to Tahiti, in 1767, the high-ranking woman Purea gave tamau to Captain Samuel Wallis and his officers" (D'Alleva 2001: 86). ${ }^{10}$ She also notes that, in 1792, 'Itia, the wife of Pomare I, gave George Tobin "a present of plaited human hair about the thickness of a double thread" (p. 86, quoting Oliver 1988: 170; see also Tobin 2007: 96), and that seven years later Pomare I's consort, Vaiareti, gave William Wilson of the Duff "a quantity of human hair made into fine sinnet" (p. 86, quoting Wilson 1966: 209). In all these cases, the givers and receivers of the gift are thought to have been taio, that is, friends with reciprocal obligations. ${ }^{11}$ As it happens, we did not have far to look for a potential source for the Forster-collection tamau. The Forsters' writings suggest a possible - though admittedly speculative and arguably excessively romantic - provenance.

The elder Forster's most significant mentions of tamau occur in his Journal entries for 11 September 1773, during the Resolution's first visit to Ra'iatea, and 29/30 May 1774, during the Resolution's second visit. In the first of these entries he provides a detailed account of the heiva or dance put on for the visitors by Reo, the Borabora regent of the island..$^{12}$ One of the dancers was Reo's daughter Poiatua (Fig. 6), ${ }^{13}$ whom Forster calls "a fine young Girl". Forster describes the dancers' appearance:

Their dress is singular \& remarkable: on their heads they had a high twist or turbant of plaited hair; on the crown in the circle between ye plaited hair all was filled with Cape Jasmin flowers \& the front of the bunch of plaited hair was ornamented with 3 or 4 rows of the white flowers of the Morinda citrifolia, which looked so pretty as if the head had been set of[f] by pearls. (Hoare 1982 [II]: 360)

Reinhold Forster was clearly struck by Poiatua's appearance and was moved to sketch either her or one of her similarly dressed companions (see Fig. 7). ${ }^{14}$ Moreover, he goes on to record that after the dance and a sort of play had finished "we made the Actors presents" (p. 361). He does not say specifically 
that Poiatua was given presents, but it seems clear that she was, and if so-we suggest - she may have given either Reinhold or George the tamau from her head in return. Such speculation is strengthened by the detailed description the elder Forster provides, especially of the flowers set into the ornament; we can imagine him writing up his journal in the Resolution's Great Cabin with the newly acquired tamau on the table in front of him.

That this may indeed be what happened is also suggested by George Forster's account in his Voyage Round the World, based in large part on his father's journal. George gives a detailed report of the same event, including a reference to "Poyadua, the fair daughter of the chief Orèa, and the other a tall well shaped lady, of very agreeable features, and likewise a very fair complexion" (J.G. Forster 1777 [v. I]: 399, 2000a: 216). With reference to the tamau he comments:

The neck, shoulders, and arms were left uncovered, but the head was ornamented with a kind of turban, about eight inches high, made of several skains [skeins] of plaited human hair, which they call tamòw. These being laid above each other in circles, which enlarged towards the top, there was a deep hollow left in the middle, which they had filled up with a great quantity of the sweet-scented flowers of the (gardenia) Cape jasmine. But all the front of the turban was ornamented with three or four rows of a small white flower, which formed little stars, and had as elegant an effect on the jetty black hair as if it had been set out with pearls. (J. G. Forster 1777 [v. I]: 399, 2000a [v. I]: 216)

Again, one can imagine George drawing on his memories - perhaps even on notes he had made - of the tamau he and his father had sent to Oxford in January 1776 as he wrote this section of his Voyage later that year. George also records the giving of presents: "The officers of both ships, who were present, and ourselves, loaded them with a great variety of beads and ornaments, which they had so well deserved" (J. G. Forster 1777 [v. I]: 399, 2000a: 217).

As for the second occasion, in his Journal for 29 May 1774, Reinhold records the sighting of a different type of tamau, but again brings his account back to Poiatua:

I took a little walk ashore \& saw two other Girls dance a Heivā. The plated Hair were not wound round their heads, but laid in locks, which looked well enough: but their performances were not so good, as those of Teipoyādòoā's, who has fine hands \& an elegant shape above (Her feet being extremely large) $\&$ her motions are extremely gracefull. (Hoare 1982 [v. III]: 525)

In his Journal for 30 May (the next day in "ship's time", which ran from noon to noon), he also records "After dinner we came again ashore to Orèà's 
house, where we saw Teipoyādòoā dance. She was more dressed out than ever" (Hoare 1982 [v. III]: 525). George provided accounts of both these events in his Voyage. Of the dance on 29 May he wrote:

I had been on shore in the creek during this time, and saw a heeva, or dance, performed by two little girls; but their dress was not so grand, and their action much inferior to that of Poyadua. The tamow, or head-dress of plaited hair, was not laid like a turban, but formed several large locks, which had a pretty effect, and resembled in some measure the high heads of our modern ladies. (J. G. Forster 1777 [v. II]: 141, 2000a [v. I]: 395)

Of the performance by Poiatua on 30 May he wrote:

In the afternoon Poyadua performed a dance; and as if she meant to outshine the other actresses, she had ornamented her dress more than usual, and wore a great quantity of various sorts of European beads. Her wonderful agility, the graceful motion of her arms, and the quick vibration of her fingers, were as much admired there by the natives, as we applaud them in our dancers; and since all these accomplishments are taught in the South Sea islands by nature only, it must be confessed that Poyadua deserved the encomiums which all the spectators bestowed upon her. (J. G. Forster 1777 [v. II]: 141, 2000a [v. I]: 395)

Taken together, the elder and younger Forsters' accounts of encountering Poiatua in September 1773 and May 1774 provide some of the very best descriptions we have of the form and nature of tamau headdresses. More than that, however, they seem to speak of a direct engagement with at least one specific example, which — we suggest—may be that preserved at the Pitt Rivers Museum. What we are suggesting, therefore, is that either Reinhold and/or George Forster may have been in a taio relationship with Poiatua and that the tamau may have been one of the gifts Poiatua gave them.

\section{DISCUSSION}

We recognise that our suggestion that the tamau headdress preserved today at the Pitt Rivers Museum was given by Poiatua to Reinhold or George Forster in September 1773 or May 1774 is speculative. There are numerous other possible histories for this object. Poiatua may have given it to one or other of them on another occasion during the Resolution's two visits. Or someone else may have presented it to Reinhold or George during one of the Resolution's visits to Ra'iatea - or during one of the visits to Tahiti. Given what is known about how "curiosities" were exchanged between the voyagers themselves, and indeed about how the Forsters sometimes purchased items from the sailors on the voyage, it may be that the tamau 
now in Oxford has a different history altogether. Among other possible scenarios, given Lieutenant Pickersgill's seemingly close relationship with Poiatua (see note 14), it is possible to imagine that Poiatua gave the tamau to him and that he subsequently gave or sold it to the Forsters. All we know for sure, admittedly, is that the tamau headdress now in Oxford was acquired on Cook's voyage of $1772-75$.

However, it is striking that all the mentions of tamau headdresses in the Forsters' accounts relate closely to Poiatua and her performances. This might lead one to expect that they would have mentioned the acquisition of a tamau from her in their writings and/or that her name would be mentioned in the relevant entry in the "Catalogue of Curiosities sent to Oxford". Anyone familiar with the Forsters' writings in general, however, knows that they rarely mention individual objects and their acquisition; frustratingly, the written accounts provide few reliable clues as to where and when individual objects were acquired - and there is no mention of the acquisition of a tamau. Moreover, with one exception-a Māori cloak from "Dusky Bay" (no. 102; see Coote et al. 2000: 188) - the entries in the Forsters' manuscript catalogue of the collection they gave to Oxford in 1776 do not include specific provenances beyond island or island group. Thus the provenance for the tamau is given only as "OTaheitee and the Society Isles".

We should also note that the Forsters appear to have collected more hair than the tamau now in Oxford. In a list the Forsters drew up in February 1778 of material they had available for sale, they refer to "des fils qu' on a fait des cheveux de leurs femmes, \& dont ils font un ornament pour leurs danseuses" (threads that they make from the hair of their women, of which they make an ornament for their dancers; our translation). ${ }^{15}$ Moreover, a "bundle of very fine, braided human hair cords" was included in the collection they gave to Fürst Leopold Freidrich Franz of Anhalt-Dessau, formerly housed in the Südsee Pavilion at Wörlitz Castle. ${ }^{16}$

For now, there is little more to add, other perhaps than to wonder whether the suggestion made by William Wales, astronomer on the Resolution, was valid. Wales suggests that the Forsters were guilty of inappropriate sexual behaviour, in his reference to "the affair of the old man and his son at Uliatea [Ra'iatea], where a girl and a knife was concerned" (Wales 1778: 55, 2000: 726; original emphases). Although refuted by George Forster as a "pretty story' (J. G. Forster 1778: 32, Forster 2000b: 770), might it relate in some way to the existence of a special (sexual?) relationship between one or the other, or even both Forsters, and Poiatua? Rather than fanning the flames of 18th-century gossip, however, we think it best to comment no further.

$$
* * *
$$




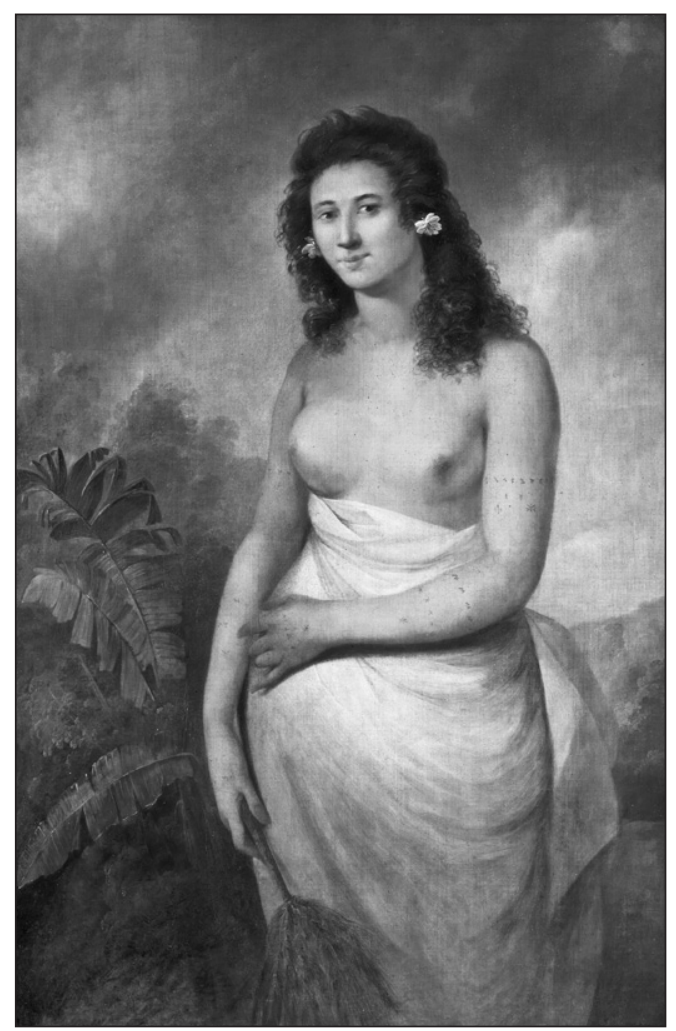

Figure 6. John Webber, Poedooa, the Daughter of Oree, 1777, oil on canvas, 1454 x $959 \mathrm{~mm}$, in the Ministry of Defence Art Collection at the National Maritime Museum (BHC2957). Webber painted Poiatua's portrait during her confinement on board the Discovery during Cook's visit to Ra'iatea on the third voyage. She is thought to have been aged 19 or so and pregnant at the time; the flowers at her ears are identified as Cape jasmine, that is, the same flowers the Forsters say were used to decorate the front of the tamau. This painting is one of at least three worked-up versions, presumably based on sketches made on board the Discovery, produced by Webber back in London after the voyage. For a detailed account of the painting, see the entry for it on the website of the National Maritime Museum, at <http://collections.rmg.co.uk/collections/ objects/14430.html>; see also Thomas 2003: 351. Courtesy and copyright, National Maritime Museum, Greenwich, London, Ministry of Defence Art Collection. 

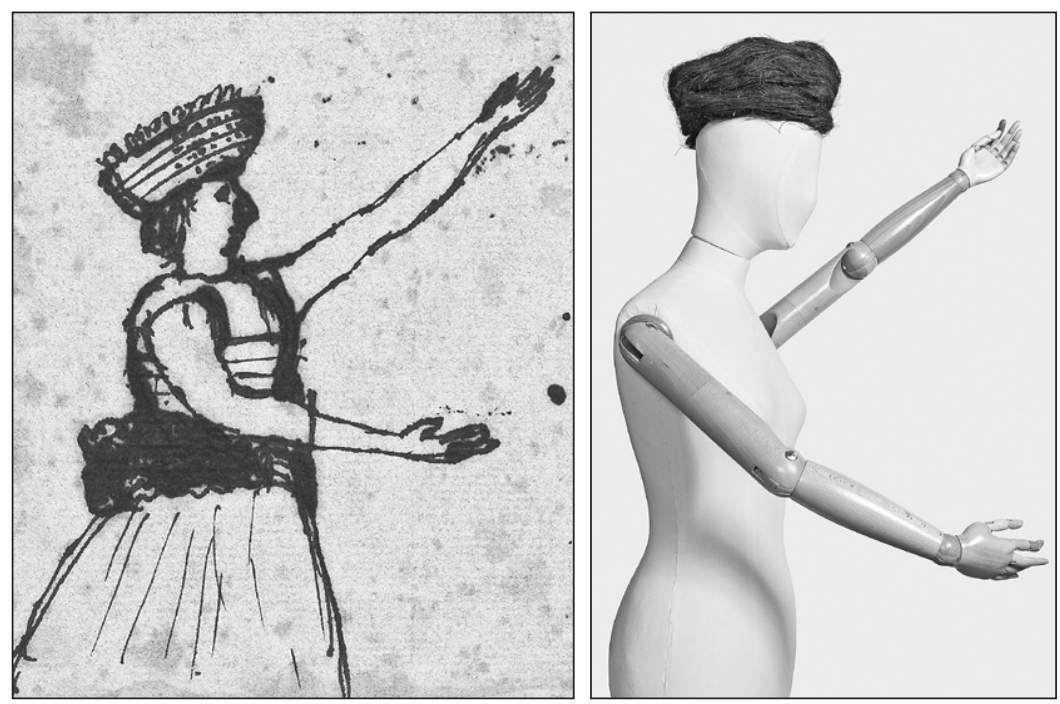

Figure 7 [left]. Johann Reinhold Forster, untitled sketch of a woman dancing, Hamanino, Ra'iatea, 11 September 1773; pen and ink, 203 x $141 \mathrm{~mm}$ : "Their dress is singular \& remarkable: on their heads they had a high twist or turban of plaited hair... Over the upper part of the Shoulders $\&$ breast a white thin cloth was spread, \& under it over the upper part of the body, the one had a brown gummed cloth, \& the other a blue Woolen European Cloth; below they were dressed in a kind of wide $\&$ long petticoat of white cloth, but about the hips on both sides there was a very large 4 rowed ruff of red \& white cloth" (Hoare 1982 [II]: 360). Staatsbibliothek Preussischer Kulturbesitz, Berlin; J. R. Forster's Journal II, MS germ. Quart. 224, opp. folio 133. Courtesy and copyright, Staatsbibliothek, Preussischer Kulturbesitz, Berlin.

Figure 8 [right].View of the tamau mounted on a mannequin in the photographic studio at the Pitt Rivers Museum in June 2012; from a photograph taken for the Museum by Malcolm Osman (PRM000130302). Courtesy and copyright, Pitt Rivers Museum, University of Oxford.

Paul Tapsell's recent speculative discussion concerning how at least some of the objects in the collection Joseph Banks gave to Christ Church, his old Oxford college, after Cook's first voyage might have belonged to the Raiatean priest-navigator Tupaia has given those objects increased intrinsic interestgreater potential mana perhaps (Tapsell 2009; cf. Coote 2004). Similarly, our speculation that the tamau preserved at Oxford might have once adorned the 
head of Poiatua is likely to give it greater appeal. In her 2001 essay, D'Alleva notes the "unprepossessing appearance" of surviving tamau: "rarely on exhibit, they sit in drawers and boxes, brittle skeins of braided hair without sheen or lustre" (D'Alleva 2001: 82). The juxtaposition here of Reinhold Forster's sketch (Fig. 7), the studio photograph of the newly discovered example displayed on a mannequin (Fig. 8), and Webber's portrait (Fig. 6) goes some way towards bringing the object to life. Certainly, it seems likely that it will now be launched on a "career" of publication and exhibition, just as the figure found in the mourner's dress at the British Museum was, once it had been published by Cranstone and Gowers in 1968 .

Our engagement with "ethnographic objects" is increased immeasurably by linking them with particular individuals, makers or owners - especially when something is known about them and we have their portraits to gaze upon. As we have endeavoured to stress, we recognise that our suggestion that Poiatua gave the Forsters this particular tamau is speculative and that there is a danger that by repeating it here it may become an unwarranted "fact". As we see it, however, attempting to identify the high-ranking woman from whom the Forsters acquired the tamau contributes to the recent shift in focus in accounts of Cook-voyage objects from the agency of the voyagers who "collected" them to that of the people who made, used, and gifted or exchanged them. In that spirit we like to imagine that the girl portrayed by John Webber is the same girl sketched by Reinhold Forster and that the newly discovered headdress is the one that adorned her head as she danced for her father's visitors on 11 September 1773 - or 30 May 1774.

\section{ACKNOWLEDGEMENTS}

We are grateful to our colleagues at the Pitt Rivers Museum - in particular Heather Richardson, Kate Jackson, Madeleine Ding and Malcolm Osman - for their assistance in the dismantling of the mourner's dress and the documentation and photography of the tamau. Uden began work on the mourner's dress - and thus the tamau - before taking up in January 2012 a Clothworkers Foundation Fellowship to work on the "Cook-voyage" collections at the Pitt Rivers Museum, but is nevertheless pleased to be able to acknowledge here the support of the Foundation, which has enabled him to contribute to the preparation of this article. Coote's work on the Forster collection and its history has been made possible by a series of grants from the Hulme University Fund (1995), the South Eastern Museums Service (1996), the Jerwood/ MGC Cataloguing Grants Scheme 1997-98 (supported by the Museums \& Galleries Commission, the Jerwood Foundation and the Department for Culture, Media and Sport), and the Innovation Awards Scheme of the Arts and Humanities Research Board (2001; award number B/IA/AN4817/APN13726). Finally, we are grateful to Anne D'Alleva, Adrienne Kaeppler and Maia Nuku for their comments on an earlier draft. 


\section{NOTES}

1. The modern form of the figure's registration number (which needs to be used for retrieving the relevant entry from the British Museum's online database) is Oc,TAH.78.a.

2. For more images of the exhibition being prepared, see Coote 2005.

3. The "Forster Collection" website was launched in 2001 (see Coote 2001b). Unfortunately, in recent years, technical difficulties have made it impossible to update the site with further information, as was originally intended. Work on a new, fully updated (and updateable!) version of the site has begun; see $<$ http:// web.prm.ox.ac.uk/cookvoyages/>.

4. Uden is currently endeavouring to see whether it is possible to identify the origins of this material.

5. University of Oxford, Pitt Rivers Museum, Accession Books etc., "List of Anthropological Objects Transferred from the Ashmolean to the Pitt Rivers Museum", 2 volumes, (compiled by Edward Evans, 1884-86). For a transcription, see MacGregor 2000: 255-413. For an account of the work of Evans and his controversial predecessor Rowell, see Ovenell 1986: 230 ff.; see also MacGregor 2000: 255 .

6. The tamau does not bear one of Evans's labels, nor any trace of one. Nor does it bear one of the small labels with handwritten numbers matching those in the Forsters" "Catalogue of Curiosities sent to Oxford" that provide indisputable evidence of an object's being part of the Forster collection. We are, however, as sure as we can be that the tamau discussed here is the object listed as number 40 by the Forsters in their manuscript catalogue. We discount the possibility that the newly discovered tamau was somehow part of the mourner's dress and that the separately listed tamau remains missing. From our knowledge of the history of the Museum's collections, we also discount the possibility of the tamau having come from a different source.

7. In his edition of Banks's Journal, J.C. Beaglehole notes that a marginal note in a hand other than Banks's records: "Jany. 21. 1772 measurd one 6144 feet another 7294 feet" (Beaglehole 1962 [I]: 339, n. 1).

8. According to Legrand et al. (2005), $120 \mathrm{~mm}$ of hair weighs roughly $0.001 \mathrm{gm}$, thus one metre of hair weighs $0.00833 \mathrm{gm}$ (i.e., $(0.001 \div 120) \times 1000)$. The hair in the Oxford tamau comprises three plys of up to ten strands each; i.e., there are no more than 30 strands in a single plait. The weight of a one metre section of the sort of plaited hair in the Oxford tamau can thus be calculated as weighing $0.25 \mathrm{gm}$ (i.e., $0.00833 \times 30$ ). Given that the Oxford tamau weighs $164 \mathrm{gm}$, we can calculate that the braided hair measures $656 \mathrm{~m}(164 \div 0.25)$. If that figure is not impressive enough, we should point out that, unbraided, the hair in the tamau would measure almost $20 \mathrm{~km}$. Alternatively, the "What Do We See: The Shaft" section of L'Oréal's Hair Science website (at <http://www.hair-science.com/>) suggests that $72 \mathrm{gm}$ of hair is equivalent to $13 \mathrm{~km}$ in length. Thus the weight of the Oxford tamau, $164 \mathrm{gm}$, would equate to $29.6 \mathrm{~km}$. Given that the hair in the Oxford tamau comprises three plys of up to ten strands each, i.e., 30 strands 
in a single plait (and leaving aside the troublesome question as to whether or not Polynesian hair weighs more or less the same as other human hair), we can calculate that the total length of the braided hair in the Oxford tamau is $0.99 \mathrm{~km}$.

9. For Roger Rose's summary of his findings concerning tamau, see Rose 1971: 795-96. Rose did not, of course, examine the newly discovered example.

10. This log book is held, like so much other material relating to the early British voyages, in the Public Records Office (PRO) collections at the National Archives of the United Kingdom (TNA): TNA:PRO, ADM 55/35.

11. In her recent book Intimate Strangers: Friendship, Exchange and Pacific Encounters, Vanessa Smith (2010) throws doubt on previous understandings of the nature of taio relationships - and even on their very existence. What remains clear and sufficient for our purposes, however, is that people gave each other things and, in particular, that elite women gave hair to European voyagers.

12. For recent accounts of the Resolution's first visit to Ra'iatea, see Salmond 2003: 206 ff., Thomas 2003: 199-200; for Cook's Journal account, see Beaglehole 1969: 223 ff. For recent accounts of the Resolution's second visit to Ra'iatea, see Salmond 2003: 256 ff., Thomas 2003: 235 ff.; for Cook's Journal account, see Beaglehole 1969: $419 \mathrm{ff}$.

13. With typical orthographic precision, Reinhold Forster gives the girl's name as Teipoyādòoā. George Forster gives Poyadua. Other voyage journalists give Poedu. Among recent authors, Salmond (2003) gives her name as Poiatua, Thomas gives Poetua, and others Poedua. For convenience's sake, we follow Salmond's (2003) usage here.

14. In his Journal, Richard Pickersgill (Third Lieutenant on the Resolution) also recorded what appears to be the same event (though there appears to have been a number of dances over the course of a few days and a number of exchanges of presents). Indeed, Pickersgill claims that he was taken ("carried", he says!?) by Poiatua to watch her being dressed for the performance: "her head dressed in the Manner of a Turband with fine Platted black hair ornamented with flowers" (see Beaglehole 1969: 771). As Beaglehole (1969: 223, n. 6) comments, "Pickersgill seems to have got on extremely well with this charmer, 'Miss Poedua'". See also the account in William Wales's Journal (Beaglehole 1969: 804-5). It would also be worth considering whether other examples of tamau that can be definitively traced to Cook's second voyage were acquired on this occasion; for example, the hair in the collection of Anders Sparrman held by the Statens Etnografiska Museum in Stockholm (see Söderström 1939: 33 and Pl. ix, Fig. 4).

15. "Nota rélativement aux Curiosités Artificielles, qu'on a rapportées de la Mer du Sud", manuscript signed by "Jean Renaud Forster" and George Forster; New Zealand, Wellington, National Library of New Zealand / Te Punā Mātauranga o Aotearoa, Alexander Turnbull Library, MS-Papers-3497; for a full transcription, see Hoare 1982 [IV]: 780-82; for an English translation, see Kaeppler 1978b; see also Dawson 1979: 12-13.

16. This is also a recent "rediscovery", reported by D'Alleva (1997: 541-42). 


\section{REFERENCES}

Beaglehole, J. C. (ed.) 1962. The Endeavour Journal of Joseph Banks, 1768-1771. 2 volumes. Sydney: Trustees of the Public Library of New South Wales in association with Angus and Robertson.

-1969 [1961]. The Voyage of the Resolution and Adventure, 1772-1775, Volume II of The Journals of Captain James Cook on his Voyages of Discovery. 4 volumes. Woodbridge: The Boydell Press in association with Hordern House, Sydney, and by arrangement with the Hakluyt Society.

Cook, James and James King, 1785. A Voyage to the Pacific Ocean Undertaken, by the Command of His Majesty, for Making Discoveries in the Northern Hemisphere. 3 volumes. 2nd edition. London.

Coote, Jeremy, 2001a. Full record for Forster number 40. In J. Coote (ed.), The Forster Collection Pitt Rivers Museum [website]. Oxford: Pitt Rivers Museum, University of Oxford [formerly accessible at <http://projects.prm.ox.ac.uk/ forster/home.html $>$ ].

_ (ed.), 2001b. The Forster Collection Pitt Rivers Museum [website], Oxford: Pitt Rivers Museum, University of Oxford [formerly accessible at $<$ http://projects. prm.ox.ac.uk/forster/home.html $>$ ].

2004. Curiosities from the Endeavour: A Forgotten Collection-Pacific Artefacts Given by Joseph Banks to Christ Church, Oxford after the First Voyage. Whitby: Captain Cook Memorial Museum.

2005. "From the Islands of the South Seas, 1773-4": Peter Gathercole's special exhibition at the Pitt Rivers Museum. Journal of Museum Ethnography, 17: 8-31.

Coote, Jeremy, Peter Gathercole and Nicolette Meister (with contributions by Tim Rogers and Frieda Midgley), 2000. "Curiosities sent to Oxford": The Original Documentation of the Forster Collection at the Pitt Rivers Museum. Journal of the History of Collections 7 (2): 177-92.

Cranstone, B.A.L., and H.J. Gowers, 1968. The Tahitian mourner's dress: A discovery and a description. British Museum Quarterly 32 (3/4): 138-44, with Pls 52-56.

D'Alleva, Anne Elizabeth, 1997. Shaping the Body Politic: Gender, Status, and Power in the Art of Eighteenth-Century Tahiti and the Society Islands. 2 volumes. Unpublished PhD thesis, Columbia University, New York. 2001. Captivation, representation, and the limits of cognition: Interpreting metaphor and metonymy in Tahitian tamau. In C. Pinney and N. Thomas (eds), Beyond Aesthetics: Art and the Technologies of Enchantment. Oxford and New York: Berg, pp. 79-96.

Dawson, Ruth P., 1979. Collecting with Cook: The Forsters and their artefact sales. Hawaiian Journal of History 13: 5-16.

Forster, Johann George, 1777. A Voyage Round the World in His Britannic Majesty's Sloop, Resolution, Commanded by Capt. James Cook, during the Years 1772, 3, 4 and 5.2 volumes. London. 1778. Reply to Mr. Wales's Remarks, London. 
2000a. A Voyage round the World. Edited by N. Thomas and O. Berghof, assisted by J. Newell. 2 volumes. Honolulu: University of Hawai'i Press.

2000b. Appendix C: A reply to Mr. Wales's remarks. In Volume 2 of his A Voyage Round the World. Edited by N. Thomas and O. Berghof, assisted by J. Newell. 2 volumes. Honolulu: University of Hawai'i Press, pp. 754-83.

Gathercole, Peter, n.d. [1970]. "From the Islands of the South Seas, 1773-4": An Exhibition of a Collection Made on Capn. Cook's Second Voyage of Discovery by J. R. Forster-A Short Guide. Oxford: Pitt Rivers Museum.

Hoare, Michael E. (ed.), 1982. The Resolution Journal of Johann Reinhold Forster 1772-1775. 4 volumes. Hakluyt Society, 2nd Series, Volumes 152-155. London: The Hakluyt Society.

Jessop, Maia, 2009. 73 Male figure $t i$ ' $i$. In A.L. Kaeppler and R. Fleck (eds.), James Cook and the Exploration of the Pacific. London: Thames \& Hudson Ltd., p. 146.

Kaeppler, Adrienne L., 1972. The use of documents in identifying ethnographic specimens from the voyages of Captain Cook. Journal of Pacific History 7: 195-200.

1978a. "Artificial Curiosities": Being an Exposition of Native Manufactures Collected on the Three Pacific Voyages of Captain James Cook, R.N. at the Bernice Pauahi Bishop Museum, January 18, 1978-August 31, 1978 on the Occasion of the Bicentennial of the European Discovery of the Hawaiian Islands by Captain Cook-January 18, 1778. Bernice P. Bishop Museum Special Publication 65. Honolulu: Bishop Museum Press.

1978b. The Cook voyage collection in Florence: Introduction. In A.L. Kaeppler (ed.), Cook Voyage Artifacts in Leningrad, Berne and Florence Museums. Bernice P. Bishop Museum Special Publication 66. Honolulu: Bishop Museum Press, pp. 71-74.

Legrand, Melissa, Carlos José Sousa Passos, Donna Mergler and Hing Man Chan, 2005. Biomonitoring of mercury exposure with single human hair strand. Environmental Science \& Technology 39 (12): 4594-4598.

MacGregor, Arthur, 2000. Manuscript Catalogues of the Early Museum Collections, 1683-1886 (Part I). British Archaeological Reports, International Series 907. Oxford: Archaeopress in association with the Ashmolean Museum, Oxford.

Oliver, Douglas, 1988. Return to Tahiti: Bligh's Second Breadfruit Voyage. Melbourne: Melbourne University Press.

Ovenell, R. F., 1986. The Ashmolean Museum, 1683-1894. Oxford: Clarendon Press.

Pedersen, Kurt Møller and Peter de Clerq (eds), 2010. An Observer of Observatories: The Journal of Thomas Bugge's Tour of Germany, Holland and England in 1777. Aarhus: Aarhus Universitetsforlag.

Psota, Thomas, 2009. 121 Woman's hairpiece tamau. In A.L. Kaeppler and R. Fleck (eds.), James Cook and the Exploration of the Pacific. London: Thames \& Hudson Ltd., p. 155.

Rose, Roger G., 1971. The Material Culture of Ancient Tahiti. Unpublished PhD thesis, Harvard University, Cambridge, Mass.

Salmond, Anne, 2003. The Trial of the Cannibal Dog: Captain Cook in the South Seas. London: Allen Lane. 
Smith, Vanessa, 2010. Intimate Strangers: Friendship, Exchange and Pacific Encounters. Critical Perspectives of Empire Series. Cambridge: Cambridge University Press.

Söderström, J., 1939. A. Sparrman's Ethnographical Collection from James Cook's 2nd Expedition (1772-1775). The Ethnographical Museum of Sweden/Statens Etnografiska Museum, Stockholm, New Series, Publication No. 6. Stockholm: Bokförlags Aktiebolaget Thule.

Tapsell, Paul, 2009. Footprints in the sand: Banks's Maori collection, Cook's first voyage, 1768-71. In M. Hetherington and H. Morphy (eds), Discovering Cook's Collections. Canberra: National Museum of Australia Press, pp. 92-111.

Thomas, Nicholas, 2003. Discoveries: The Voyages of Captain Cook. London: Allen Lane.

Tobin, George, 2007. Captain Bligh's Second Chance: An Eyewitness Account of His Return to the South Seas. Edited by R. Schreiber. London: Chatham Publishing.

Uden, Jeremy, 2011a. From the islands of the South Seas: The biography of a Tahitian mourner's costume. In A. Fischer and G. Eggert (eds), The Life of Things: The Preservation of Ethnographic Objects and Their Stories-Extended Abstracts. Stuttgart: Staatliche Akademie der Bildenden Künste Stuttgart, pp. 22-25.

-2011b. The conservation of a Tahitian mourner's costume. Poster presented at 'Cultural Heritage / Cultural Identity: The Role of Conservation', the 16th Triennial Conference of the International Council of Museums - Committee for Conservation, held in Lisbon, Portugal, 19-23 September 2011.

Wales, William, 1778. Remarks on Mr. Forster's Account of Captain Cook's Last Voyage Round the World, In the Years 1772, 1773, 1774 and 1775. London.

2000. Appendix B: Remarks on Mr. Forster's account of Captain Cook's last voyage round the world, in the years 1772, 1773, 1774 and 1775. In Volume 2 of George Forster, A Voyage Round the World. Edited by Nicholas Thomas and Oliver Berghof. Honolulu: University of Hawai'i Press, pp. 698-753.

Wilson, J., 1966 [1799]. A Missionary Voyage to the Southern Pacific Ocean, 1796-1797. Graz: Akademische Druck und Verlagsanstalt.

\section{ABSTRACT}

In July 2010, a Society Islands' tamau, or headdress of human hair, collected on James Cook's second famous Pacific voyage of 1772-74, which had been missing since 1776, was "rediscovered" at the University of Oxford's Pitt Rivers Museum. A report of its rediscovery is followed by a technical description, an account of its conservation, and a partly speculative discussion of its history and provenance.

Keywords: Society Islands, Cook's voyages, collections, museums, ornaments 
